\title{
The Development of Psycho-Didactic Skills within Special Art Education Projects
}

\author{
Hana Stadlerová ${ }^{*}$
}

\begin{abstract}
The paper presents the possibilities of developing the psychodidactic skills of students participating in a new pedagogical practicum conducted by the Department of Art of Masaryk University in Brno. Special art education (SAE), a program primarily designed for sociallydisadvantaged clients, imposes specific requirements on leading art activities. The students became part of a qualitative research program, which was implemented from 2010 to 2013 and which helped to articulate which psycho-didactic skills each student already had; this was accomplished through the implementation of specific art activities with clients from five participating institutions. The paper presents a part of the results of the research.

Key words: Special Art Education, theoretical background, professional training, teaching practice, pedagogical practicum, art projects, students of Special Art Education, clients of Special Art Education, students' psychodidactic skills.
\end{abstract}

\section{Introduction}

Art education (AE) has fulfilled many goals during its history. Since the beginnings of teaching, when it was mainly a methodological training of fine crafts, it has been gradually changing and emphasizing different priorities which are not only reflected in teacher training at faculties of education, but mainly in the actual implementation of specific art projects. New possibilities of applying art activities even outside the school practice have been reflected within the professional training at the Faculty of Education at Masaryk University in Brno. Since 2007, a new field of study called Special Art Education (SAE) has been accredited there. It carries out an interdisciplinary study which targets the training of experts in SAE, which is primarily focused on working within disadvantageous social conditions (cf. Accreditation materials, 2007).

Special Art Education prefers activities which emphasize creative thinking. If a creative personality is characterized by a number of characteristics, such as curiosity, competence, ingenuity, emotional stability, independence, selfconfidence, activeness, self-discipline, determination, perseverance, frustration,

\footnotetext{
* Hana Stadlerová, Masaryk University, Brno, Czech Republic; hanastadlerova@seznam.cz
} 
tolerance, and mental health (Hlavsa and Jurčová, 1978), then SAE must promote creative and specific activities within the designated needs of the disadvantaged clients. Special Art Education can be interpreted as a form of "creativity training" which "expands the sphere of activity of an individual, it improves perception and reaction and teaches activity, concentration, flexibility of action, and dynamic change of views" (Havlík, cited in Fišer, Havlík and Horáček, 2010, p. 99). The development of creativity is crucial because it is connected with the possibilities of solving a variety of problems which the socially disadvantaged clients encountered in their everyday lives; situations in which they should express active behavior and seek possible alternatives in order to resolve the dilemma. SAE can be labelled as a space for education through art, because, as Herbert Read says, "art education is conducive to intellectual, emotional and spiritual growth" (1967, p. 9). The concept of SAE was first theoretically described in the publication by Zbyněk Zicha (1981); its content corresponds with the objectives of art therapy and also with the work of educators in the process of special education (cf. Zicha, 1981, p. 3). SAE prefers the art-philetic approach, which is associated with Jan Slavík. Arte refers to the word art (from the Latin ars/artis), but also to art therapy. Philetic comes from the Greek root word -fil-, expressing a positive attitude towards something. SAE is also inspired by the idea of Henry Broudy's philetic (positive, affirmative) approach towards education, "in which, the intellectual development is closely linked with the emotional and social development" (cf. Slavík, 2011, p. 12).

The artphiletic approach is one of the current approaches to art education. It is characterized by intense activity and an emphasis on creativity, expressiveness, experience in art activities and subsequent reflection (cf. Slavík, 2009, 2011). Other approaches of art education, including human-centred art education concept (originally in the Czech language: "animocentrismus"), are connected with spiritual and sensory education and with principles of humanistic education as well as with art-philetics. The human-centred art education concept emphasizes the role of the object of the educational activity, regardless of whether it is a child or an adult. This attitude is based on experience and strong emotion which motivate art activity. An interest in each person who is seen and respected as an individual, is also associated with humanistic psychology. There are two leaders who represent this idea, Abraham Maslow and Carl Rogers. The idea of Maslow, who believed in the ability of self-realization as a way to discover and improve personally, is still relevant to us. The author regards creativity as the most important component of self-realization. Rogers emphasizes an update tendency in each individual, i.e. the tendency to growth, development and implementation of positive possibilities (cf. Krivošíková, 2011, pp. 81-82). SAE integrates other art forms and deliberately merges art with dramatic or musical means of expression. Therefore, it can be described as interdisciplinary. Creative expression thus becomes a place for the client to express his/her own experiences, feelings and wishes. Many of the socially 
disadvantaged clients have had traumatic experiences and harsh living conditions and that is why SAE encourages mental strength and the prevention of social failure. In general, the society should be looking for ways to mitigate stressful situations and pressures which clients have been exposed to.

Special Art Education therefore offers an opportunity to develop the positive personality traits of each individual and, thus, can become a space for preventing and tackling issues of the socially disadvantaged, but primarily the selfrealization of monitored groups of clients.

\section{Research methods}

Between the years 2010-2013, a project called Special Art Education (SAE) was conducted with the support of the Department of Art of Masaryk University in Brno. It offered an opportunity to students of art fields to implement art activities at chosen institutions, with which cooperation had been established.

The professionally-led teaching practice brought about many interesting experiences and specific outcomes; one of them was the inclusion of the results in the following specialized publications issued in 2013: Eisenhammerová, B., Strakošová, Z. et al. "CREATIVE HELP: Creative Workshops for People with Disabilities" (in the Czech language: Tvirči dilny s lidmi se zdravotním postižením), Kovářová, M., Poláková, J. et al. "CREATIVE HELP: Creative Workshops with Roma Children" (in the Czech language: Tviorči dillny s romskými dětmi), Nováková, M., Landová, M. "CREATIVE HELP: Creative Workshops with Children from the Diagnostic Department" (in the Czech language: Tvưrči dílny s détmi z diagnostického ústavu), Stadlerová, $\mathrm{H}$. et al. "CREATIVE HELP: Creative Workshops with Seniors" (in the Czech language: Tvưrči dilny se seniory), and Kamenický, P. et al. "CREATIVE HELP: Creative Workshops with Refugees" (in the Czech language: Tviorči dilny s uprchliky).

These articles present the results of an action research conducted within preparation for and during the creative workshops. This paper presents a part of the results from the SAE research project. The paper also tries to further define which psycho-didactic skills should be characteristic of leading art activities of the socially disadvantaged clients. The term "psycho-didactics" emerged in the early 90 's of the $20^{\text {th }}$ century. This is the "new interdisciplinary approach linking theory and knowledge of general didactics, psychology of learning, cognitive psychology and other branches of knowledge, its core is the realization that educational processes (not only in the school setting) are also necessary to explain the psychological considerations." (Pedagogical dictionary, 2003, p. 192) As stated by J. Škoda and P. Doulík, "educational practices must ultimately respect the individual learning characteristics of individuals, in particular their individual learning styles." (2011, p. 143) SAE should respect, among others, the individual characteristics of each personality as well as their drawing typology. 
Psycho-didactic skills can be seen as part of a student's competencies which include a psychosocial component (human), a project component (designing of an educational situation), and an implementation component (Slavík, cited in Hazuková, 2000, p. 22). The psycho-social components presuppose the mental stability of the teacher, his/her social intelligence, social responsiveness and motivation to work for others. A project component is defined as the motivation and readiness to create a psycho-didactic project (designing, preparing and planning it). The implementation component of a psycho-didactic competence is characterized by the motivation and readiness of teachers to implement an instructional model and achieve the intended goals within the current conditions. The feedback component of a teachers' competence is reflected in their motivation and readiness to remember, analyse, structure, describe and evaluate the progress and results of their own teaching (cf. Slavík, 2000, p. 22).

As mentioned above, the research was carried out at selected institutions as a part of teaching practice, which took place at those institutions. The course of the project was studied by direct observation, without intervention, and the results were enriched by the notes from pedagogical journals and written reflections of practicing students (two hundred and six texts). In addition, interviews were conducted with a psychologist who led reflexive seminars and discussions with the project leader of Special Art Education. Some valuable information was also obtained from the interviews with selected clients.

The materials were analysed by the method of open coding (cf. Švaříček and Šed'ová, 2007) which brought about important conclusions. These conclusions could improve the content of the SAE program, but more importantly, improve the experience of students in the pedagogical practicum and offer other benefits to other social workers who offer art activities to their clients.

\section{Research results}

If we want to identify the special psycho-didactic skills in a student of art, it is necessary to notice the students' core art skills which are also prerequisites to be accepted to study at the Art Department. According to the research, there has been a shift in the priorities of skills of students. The psychologist, who works with students in a reflective seminar, analysed and concluded that students understand their future job (teacher or social worker) as a helping profession. Art abilities and art self-realization are also important areas for them, but it is not the main goal (i.e. to be a great artist who also teaches). They mostly perceive the development of their art abilities as a way of how to name their real talents, limits and identify starting points for future art projects focused on a specific group of clients. According to the psychologist of this project, "the target group of clients with special needs is the professional goal the students are aiming to serve". The students' art skills and experiences should be as varied as possible in order to offer clients as many of approaches as possible. This also confirms the 
idea of I. Zhoř, who highlights the risk of learning "according to myself" in the sense of a transfer-only personal model of creativity (1998, p. 16), "The teacher should not promote only himself or herself, showing students just his/her subjective ideas and showing personal methods of creation. Rather, he/she should probably see a different individuality in their students and respect the different types of art orientation; also find a relationship to each of them; find a positive attitude, understanding and wisdom." The research also shows that students of SAE exhibit acts of sincere interest in promoting and developing the creative activity for "other" individuals. They respect their situation, health status, etc., which often led (individuals) to social disadvantage. They realized that "being a socially disadvantaged individual is a result of their social status brought on by a restricted access to certain social and material goods." (Pedagogický slovník, 2008, p. 216). Students of the SAE program can be described as empathetic individuals with prosocial feelings which are not trying to exploit the situation for their own self-promotion. As the psychologist comments on the project, "students are not narcissist, they do not need to prove anything." This description is typical especially for those students who benefit from the experience of undertaking pedagogical (teaching) practice and have a clear understanding of the SAE studies and its content.

There is also an interesting comparison of the results of reflections by the students who completed the SAE studies to when they were studying it; at the beginning of their studies, students usually prioritized art education more, learned art skills and experienced their own creative fulfilment. As time went by, and as students started participating in pedagogical (teaching) practice projects led by experienced instructors, they focused more on the process of creative activities for others, building a creative environment, etc. New knowledge and point-of-view was also brought to theoretical courses where they had the opportunity to learn the specifics of different institutions (i.e. retirement homes). They were apprised with the characteristics of the clients, with the system of leisure activities, progress and the results of already implemented creative activities.

In their own projects, students also benefited from the experience of their colleagues. It should be noted, however, that it applied primarily to students' own ideas which were creatively seized. They were open to the suggestions of other employees, but also to the clients of institutions. Openness and cooperation of students were not always automatic. They encountered situations where cooperation with more students was stalled because each individual insisted on following his/her idea by championing his own concepts and opinions. This kind of situations subsequently became the subject of reflection, analysis and generalization. The clients should always be seen as the centre of interest, including their needs. The completed projects also showed that even the best possibly planned and scheduled projects brought some unpredictable moments, in which students found themselves with clients and these needed flexibility. As 
activities were always optional (for clients), the input motivation played an important role in motivation which awakened an interest to create.

One of the factors affecting participation was the attractiveness of the activities. They were designed to awaken the interest of clients to try something new and unknown. To do that, students drew their inspiration from their own creative experience, but also equally from the stimuli of contemporary art or new knowledge obtained from the course of new media. It should be emphasized that art creation wasn't done only with the purpose to make fancy outputs. We appreciate that the students offered to clients many activities which were enriching because of their process and procedure. Project outputs were: video recordings, photos, audio recordings, etc. Projects like these required a high degree of communication skills of students and their ability to listen and be patient to guide the clients. The students' reflections also showed that it was difficult to connect, to gain a client's trust; their willingness to "open up" is not commonplace. Therefore, the projects which responded to clients stories of their life required the establishment of a closer relationship between the participants of the creative activities and leaders. It should be mentioned that the psychologist (therapist) required being present to encourage the professional relationship between a client and a special art teacher. Due to the presence of a therapist, it was easier for a special art teacher to keep a particular perspective and distance, protecting him/herself from burnout, unhealthy sympathy towards the problems of the clients, or identifying with his living situation, etc.

This phenomenon threatened students while leading activities with clients who they were close to in terms of age (e.g. children from diagnostic facilities, foreigners in refugee camps). Communication with seniors was also demanding, where respect for the patients sometimes conflicted with their elderly unexpected emotions (moody, moodiness, self-centeredness, etc.). It was often difficult to convince elderly people to overcome their initial scepticism and concern that activities can be done and they had a purpose. Therefore, students especially appreciated activities which were accepted by the clients and it was obvious that the act of creation brought intense experiences to them. It also often encouraged other clients to participate in subsequent art projects, to overcome stereotypes or fight an initial reluctance to participate in the events.

We can say that the realised projects of Special Art Education were a valuable opportunity for the implementation and the development of psycho-didactic skills. Additionally, it upheld the needs of creative activities and their importance, especially in institutions like retirement homes or refugee camps, where creative programs are not often considered an important part of a care. 


\section{References}

FIŠER, Z., HAVLÍK, V. and HORÁČEK, R. Slovem, akcí, obrazem. Př́ispěvek $\mathrm{k}$ interdisciplinaritě procesu. Brno: Masarykova univerzita, 2010.

HAZUKOVÁ, H. Připrava učitele na rozhodováni ve výtvarné výchově I. Praha: Univerzita Karlova v Praze, Pedagogická fakulta, 2000.

HENDL, J. Kvalitativni výzkum. Praha: Portál, 2008.

HLAVSA, J. and JURČOVÁ, M. Psychologické metódy zistovania tvorivosti. Bratislava: Psychodiagnostické a didaktické testy, 1978.

KRIVOŠÍKOVÁ, M. Úvod do ergoterapie. Praha: Grada, 2011.

PRŮCHA, J., WALTEROVÁ, E. and MAREŠ, J. Pedagogický slovnik. Praha: Portál, 2008.

SLAVÍK, J. Uměni záżitku, zážitek umění. Teorie a praxe artefiletiky. 1st. part. Praha: Univerzita Karlova v Praze, 2011.

ŠVǍ̌ÍČEK, R., ŠEĎOVÁ, K. et al. Kvalitativní výzkum v pedagogických vědách. Praha: Portál, 2007.

STADLEROVÁ, $\mathrm{H}$. et al. Creative help - tvưrči dilny se seniory. Brno: Masarykova univerzita, 2013.

ŠKODA, J. and DOULÍK, P. Psychodidaktika. Psychologické metody efektivního a smysluplného učení a vyučováni. Praha: Grada, 2011.

ZHOŘ, I. Vzdělávání učitele je vzděláváním osobnosti. Horizonty vzdělávání učitele výtvarné výchovy, Sborník symposia INSEA 1997. Praha: Univerzita Karlova v Praze, Pedagogická fakulta, 1998.

ZICHA, Z. Úvod do speciální výtvarné výchovy. Praha: Univerzita Karlova v Praze, 1981. 